\title{
Editorial
}

\section{Trampolins para o aquecimento nos debates: artigos como fonte de produçõ̃es incessantes}

\author{
Trampolines for warm up in debates: articles as a source \\ of incessant productions
}

Assumo, temporariamente, a editoria deste respeitável periódico, com o apoio fundamental da equipe do Núcleo de Publicação de Peridiódicos do CFH/UFSC, cuja experiência certamente contribuirá consideravelmente para o andamento da Revista de Ciências Humanas. Por sua característica multidisciplinar, este periódico abraça as ciências humanas e sociais colocando-a no horizonte da produção acadêmica a partir do exercício da divulgação de trabalhos originais.

A editoria é exercício nobre, privilegiado, pois se tem acesso à relatos e reflexões que artigos engendram, antes mesmo desta produção poder se fazer objetivação coletiva e gerar novas reflexões e debates. Outro dia, em conversa com um grande amigo e experiente editor, comentávamos o quão interessante e importante era na década de 80 o debate gerado a partir de artigos publicados em periódicos diários. Eram artigos de cunho filosófico e político, de grande alcance epistemológico, onde se discutia a ciência e sua implicação na construção cotidiana de um mundo melhor. Os debates eram interessantes, pois aconteciam a partir da leitura de artigos publicados, que geravam novas reflexões e, quiçá, novos experimentos.

Nossa conversa trouxe o desejo e a expectativa que as produções científicas divulgadas em periódicos pudessem reviver a função do debate acadêmico, tão importante e fundamental para o avanço do conhecimento científico. É apoiada nesta perspectiva que abro este número da Revista de Ciências Humanas, esperando novas produções a partir desta.

O primeiro artigo, intitulado "A criança amada e odiada: uma análise do status controverso", de autoria de Bruna Camillo Bonassi, Mauro Luís Vieira, Ana Maria X. Faraco e Kenneth H. Rubin, discute uma pesquisa que caracteriza o status controverso em crianças e relaciona este status social à percepção da criança sobre suas relações com amigos e pais e à percepção dos professores sobre a criança controversa. Os resultados são discutidos levando em consideração a qualidade dos relacionamentos sociais e o bem-estar psicológico da criança.

Flavio Santiago e Adriana D. de Souza Carvalho no artigo "Políticas Públicas e Direitos Humanos: uma releitura das Relações Raciais nas Escolas 
Brasileiras", analisam as Diretrizes Curriculares Nacionais para a Educação das Relações Étnico-raciais e para o Ensino de História e Cultura Africana e Afrobrasileira e mostram que a construção do olhar dos educadores não deve se pautar na lógica da negação dos direitos humanos, mas recusando a homogeneização e institucionalização de práticas inclusivas. A partir do conceito de "hipermodernidade" e das contribuições da psicanálise, o artigo "Pinóquio e a escola hipermoderna: reflexões sobre o sentido da educação na sociedade contemporânea", de autoria de Sanny S. da Rosa, reflete sobre aspectos da cultura contemporânea que afetam e desconcertam a tarefa educativa, refletindo sobre os sentidos da escola.

O artigo "Jovens Autonomistas do Centro de Mídia Independente e o velho vestido de novo", de autoria de Carlos André dos Santos, trata a participação política dos jovens em ações coletivas de contestação ao estabelecido na mídia radical alternativa, trazendo que muitas vezes o "velho" se apresenta como "novo", mantendo o objetivo de manutenção e adaptação dos jovens ao sistema de produção capitalista e aponta, assim, as possibilidades e limites da atuação política.

Isadora Vier Machado, Letícia Cardoso Barreto e Miriam Pillar Grossi, no artigo "Processos de Ensino e Aprendizado de Gênero e Sexualidades em Contextos Interdisciplinares", refletem sobre o processo de ensino e aprendizado de gênero e sexualidades em contextos interdisciplinares, a partir de experiências discentes e docentes, refletindo acerca das características, limites e os efeitos desses processos.

O artigo "Análise Etnográfica e Discursiva das Relações entre Estado e Mulheres Indígenas Encarceradas no estado de Mato Grosso do Sul”, de autoria de Simone Becker e Lívia Estevão Marchetti, a partir da análise de discurso de vertente foucaultiana e da análise etnográfica, imergem em enunciados que compõem "aldeias arquivos" de condenações criminais de mulheres indígenas do sul mato-grossense. Nei Antônio Nunes no artigo "Investigando as categorias foucaultianas: o olhar genealógico sobre os modos de condução das condutas", analisa as noções foucaultianas de acontecimento, dispositivo e regime de verdade, explicita as categorias de governo e governamentalidade e mostra sua relação com os processos modernos e contemporâneos de condução das condutas.

"Identidade e Personificação do Lugar na Apropriação do Espaço pelos Nativos de Ibiraquera, SC" é o artigo de autoria de Rosa Nadir Teixeira Jerônimo e Teresinha Maria Gonçalves que nos traz o processo de apropriação desse espaço, a partir do enfoque teórico da Psicologia Ambiental, mostrando que a identidade de lugar e a personificação do lugar se complementam. Juliana F Cecato, José Eduardo Martinelli, Luana L. Bartholomeu, Patricia P. Ferreira, José Maria Montiel e Daniel Bartholomeu, no artigo "Correlações entre Aspectos da Memória e Aprendizagem em População Idosa", objetivou avaliar 
as capacidades de aprendizagem em idosos que frequentam uma Faculdade da Terceira Idade em um município do interior de São Paulo. O artigo "Contribuição das Âncoras de Carreira para Entender Diferenças e Similaridades de Gênero e Profissão na Geração Y", de autoria de Dione Fagundes Nunes Gomes, Leonardo Nelmi Trevisan, Elza F. Rosa Veloso e Rodrigo Cunha da Silva, investiga o impacto das variáveis "área de atuação" e "gênero" nas âncoras de carreira de pessoas da Geração Y.

Por fim, duas resenhas fazem parte deste número: "Psicologia Ambiental: múltiplos olhares sobre as relações pessoa-ambiente" de autoria de Camila Klein; e "Usos do Passado e Escrita da História" de autoria de Diogo da Silva Roiz.

Desejamos a todos uma ótima leitura, torcendo para que estes artigos sejam fonte para futuros e incessantes debates.

Katia Maheirie

Editora geral 